\title{
亜鉛欠乏ラットによる食餌タンパク質レベルの 選択摂取
}

\author{
則 井 孝 文*, 鈴 木 博 雄** \\ *宇部短期大学

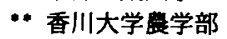

\author{
Selective Ingestion of Dietary Protein Level \\ in Zinc-deficient Rats \\ Takafumi NORII* and Hiroo SUZUKI** \\ *Ube College, Ube 755 \\ * Department of Bioresource Science, Kagawa University, \\ Kida-gun, Kagawa 761-07
}

\begin{abstract}
Nippon Eiyō Shokuryō Gakkaishi (J. Jpn. Soc. Nutr. Food Sci.) 48, 49 56 (1995)
The effects of zinc deficiency on the responses of rats in selecting dietary protein were investigated in growing rats. Two diets of $10 \%$ and $20 \%$ demineralized soy protein were given simultaneously to rats for 11 days after feeding then with either a zinc-adequate $(25 \mathrm{ppm} \mathrm{Zn})$ or a zinc-deficient diet $(\leqq 0.3 \mathrm{ppm} \mathrm{Zn})$ for 10 days. Rats in the zinc-adequate group selected the $20 \%$ protein diet more frequently than rats in the zinc-deficient group. No differences were found between zinc-adequate and zinc-deficient rats in selecting the $10 \%$ protein diet. Zinc-deficient rats showed a reduced tendency to select the $20 \%$ protein diet. When zinc-deficient rats were offered a choice between $0 \%$ and $20 \%$ protein diets, they ate preferentially the non-protein diet 9 days after presentation of the diets. Zinc-deficient rats that selectively fed on these diets survived longer than those that fed on either the $0 \%$ or $20 \%$ protein diet alone. Serum alkaline phosphatase activity and the femur zinc concentration in zinc-deficient rats were decreased to a lesser extent in the group allowed to select the diet than in the group given the $20 \%$ protein diet. These results suggest that rats may regulate their intake of dietary protein to maintain their body zinc status.
\end{abstract}

Key Words zinc deficiency, selection, dietary protein levels, zinc status.

亜鉛欠乏条件下で20\%タンパク質飼料を摂取した ラットは $10 \%$ タンパク質眗料を捸取したラットに比べ て, 血清アルカリフォスファターゼ活性, 血清および大

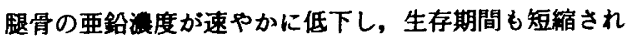
たことから，20\%タンパク質飼料を摄取したラットで体 内の亜鉛状態はより不足に傾いていることが示唆され だ。このことは垔鉛欠乏条件下ではタンパク質摄取量 の少ないラットのほうが生存に有利であることを示唆し ている。 Reeves and O'Dell ${ }^{21}$ は亜鉛欠乏条件下でラット は高タンパク質飼料よりも低タンパク質飼料を多く選択 するようになることを報告している。

- 7755 宇部市文京町 5-40

** テ 761-07 香川県木田郡三木町池戸
Chesters and $\mathrm{Will}^{3}$ は, 20\%タンパク質飼料条件で は, 亜鉛適量趼料群のラットと比較して亜鉛欠乏飼料群 の飼料摂取量が減少したか， $5 \%$ タンパク質飼料条件て は垔鉛欠乏飼料群の飼料摂取量は亜鉛適量飼料群と比へ て有意な変化がないことを報告している。Griffith and Alexander" も30\%および7\%タンパク質飼料を用いた 実験で同様な結果を報告した。これらの内容は飼料摂取 重が亜鉛欠乏群でつねに減少するのではなく，むしろ亜 鉛欠乏群の飼料摂取量の減少は飼料タンパク質含有量と

関係があることを示唆している。

垔鉛欠乏飼料を胃管を用いて強制投与したラットは対 照群と同じ成長を続ける(5) ことから，亜鉛欠乏飼料を 自由に攝取させたラットの飼料摂取量が数日のうちに減 少する8) 101 のは飼料を利用できないというより，啫好の 
50

変化"1)，食欲の減退"などの理由が考えられる。

本実験では，ラットの体内亜鉛状態とタンパク質摂取 量との関係を調へるため要鉛欠乏および正常状態のラッ トにタンパク質含量の異なる 2 種類の飼料を与えて選択 させる実験を行った。

\section{実 験 方 法}

分離大豆タンパク質（フジプロ-RB，不二製油浰）を 塩酸酸性下（pH 4.5）で洗浄して脱塩"し，乾燥したの ちタンパク質源として用い， $10 \%(1.6 \% \mathrm{~N})$ および $20 \%$ (3.2\% N) タンパク買を含む亜鉛欠乏眗料を調製した

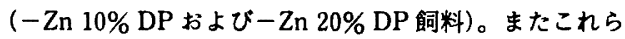
の飼料へ塩化严鉛を添加して亜鉛气を $25 \mathrm{ppm}$ とした姛 料も調製した $(+\mathrm{Zn} \mathrm{10 \% DPおよび}+\mathrm{Zn} 20 \% \mathrm{DP}$ 铜 料)。飼料組成を Table 1 に示す。亜鉛欠乏飼料中の亜鉛 含有量は原子吸光法によって分析したところいずれも $0.3 \mathrm{ppm}$ 以下であった。

動物は 3 週淽の Wistar 系雄ラット（本エスエル シ一) を用い, 一定の体重に達するまで2〜3 日間 20\%力 ゼイン飼料 (12 ppm $\mathrm{Zn})$ と脱イオン水を自由に与えて飼

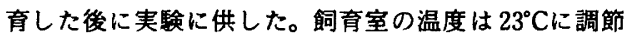
し，08〜20 時に点灯した。体重および飼料摄取量の測定 は毎朝行った。

実験 I. 摄取スケジュールはFig. 1に示すように 2 回に分けて実験を行った。まず，前飼料として $10 \% \mathrm{DP}$ 垔鉛欠乏飼料および $10 \%$ DP 严鉛適量飼料を 2 群の ラットに 10 日間攝取させた。その後, 各群をさらに 2 群 に分け, 亜鉛欠乏条件で $10 \%$ DP と $20 \%$ DP 飼料の 2 種 類の飼料を同時に与えるか，または垔鉛適量の条件で $10 \% \mathrm{DP}$ と $20 \% \mathrm{DP}$ 飼料の 2 種類の飼料を同時に与え, 11 日間自由に選択摄取させた（実験 I-1)。また別に同様 な亜鉛条件下で前飼料として $20 \%$ DP 飼料を 10 日間摂 取させた後， 2 種類の飼料を選択摄取させた（実験 I-2）。
日本栄莜・食粗学会誌

実験 II. 前飼料として, 垔鉛欠乏条件下て $10 \%$ DP と $20 \% \mathrm{DP}$ 飼料の 2 種類の飼料を同時に与える群と, 亜 鉛適量の条件て $10 \%$ DP と $20 \%$ DP 飼料の 2 種類の飼 料を同時に与える群に分け, 10 日間自由に選択摄取させ た。その後各群をさらに亜鉛欠乏群および㩊鉛適量群の 2 群に分け, $10 \%$ DP と $20 \%$ DP 飼料の 2 種類の飼料を 11 日間選択摂取させた（Fig. 1)。

実駚 III. ラット 24 匹をいずれも垔鉛欠乏条件で,

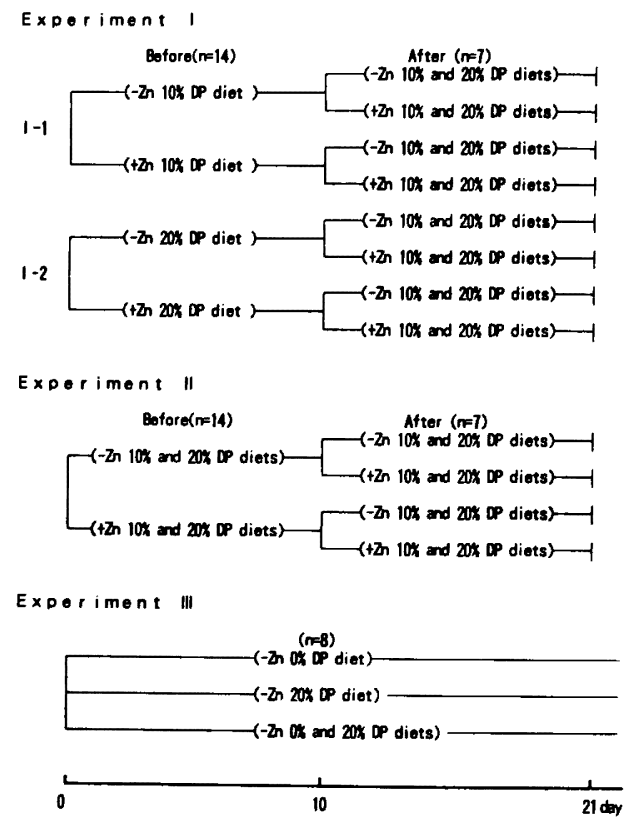

Fig. 1. Feeding schedule (Exp. I, II and III). $-\mathrm{Zn}$, zinc deficient diet $(\leqq 0.3 \mathrm{ppm}):+\mathrm{Zn}$, zinc adequate diet $(25 \mathrm{ppm})$.

Table 1. Composition of experimental diets.

\begin{tabular}{|c|c|c|c|c|}
\hline Ingredients & $\begin{array}{c}20 \% \text { Casein } \\
(\%)\end{array}$ & $\begin{array}{c}0 \% \text { DP } \\
(\%)\end{array}$ & $\begin{array}{c}10 \% \text { DP } \\
(\%)\end{array}$ & $\begin{array}{c}20 \% \text { DP } \\
(\%)\end{array}$ \\
\hline Casein & 20 & - & - & - \\
\hline Demineralized soy protein (DP) & - & - & 11.4 & 22.8 \\
\hline Salt mixture $(+Z n)^{\text {a) }}$ & 4 & - & - & - \\
\hline Salt mixture $(-Z n)^{a / b)}$ & - & 4 & 4 & 4 \\
\hline Vitamin mixture $\mathrm{e}^{\mathrm{a})}$ & 1 & 1 & 1 & 1 \\
\hline Corn oile & 5 & 5 & 5 & 5 \\
\hline Cellulose powder & 4 & 4 & 4 & 4 \\
\hline Choline chloride & 0.15 & 0.15 & 0.15 & 0.15 \\
\hline Sucrose & 65.85 & 85.85 & 74.45 & 63.05 \\
\hline
\end{tabular}

a) Harper's mixture ${ }^{1122)}$. b) Zinc was not added to the salt mixture. ${ }^{\text {c) }}$ This contained (per $100 \mathrm{~g}$ diet) : retinyl acetate, $600 \mathrm{IU}$; ergocalciferol, $60 \mathrm{IU}$; and $d l-\alpha$-tocopheryl acetate, $10 \mathrm{mg}$. 


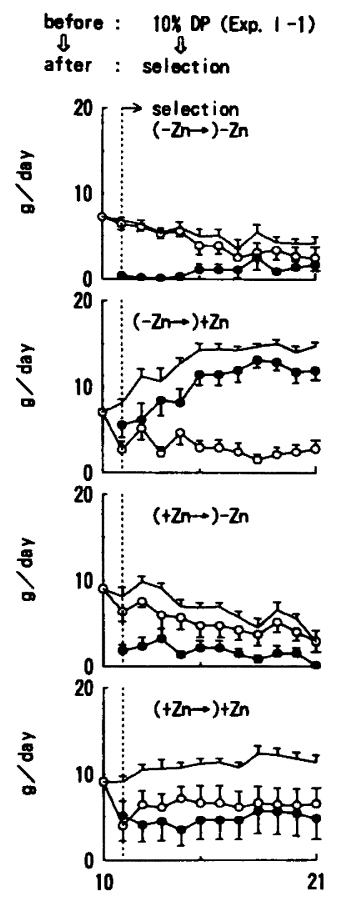

day

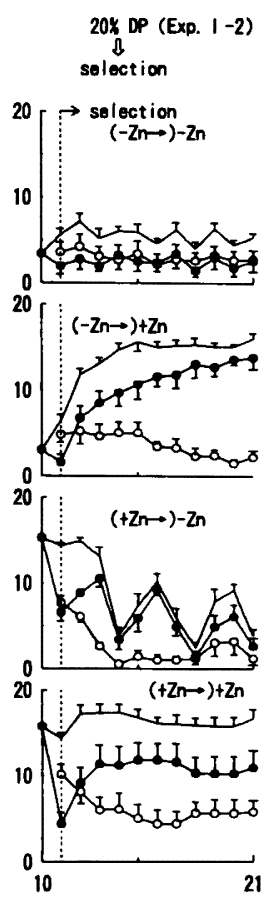

day

Fig. 2. Changes in food intake of rats selectively fed $10 \%$ and $20 \%$ demineralized soy protein diets with or without added zinc (Exp. I ).

$\therefore$, 10\% DP diet: $\bullet, 20 \%$ DP diet : - total amount of food intake. Values are means \pm SEM for 7 rats.

無タンパク質 $(0 \% \mathrm{DP})$ 知料単独群, $20 \% \mathrm{DP}$ 飼料単独 群および 0\% DP と 20\% DP 飼料の 2 種類の飼料を同時 に与える選択群の 3 群に分け, 飼料を自由に摂取させた (Fig. 1)。

ラットをエーテル麻酔下で開腹し,心葴より採血した。 血清アルカリフォスファターゼ活性, 血清および大腿骨 の亜鉛浱度は既報 ${ }^{(3)}$ に従って定量した。

得られた結果を分散分析し, 平均値の差の検定は Newman-Keuls の方法"14) および $t$-検定にて行った。

\section{結果および考察}

1. 前銅料中のタンパク筫レペルおよひ亜鉛岳が垔鉛 欠乏ラットの铜料逪択性に及ばす影需（実験 I)

高, 低タンパク質飼料の摄取量および総摄取量の変化 を Fig. 2 に示す。前飼料として亜鉛欠乏および重鉛適量 の $10 \%$ DP 飼料を摄取させた場合, 後半の選択 1 日目に

は垔鉛欠乏条件ではすで高タンパク質飼料に比べ低夕 ンパク質飼料を多く選択した(実験 I-1)。亜鉛欠乏および 亜鉛適量の 20\% DP 飼料を前飼料として摄取させた後， 高, 低タンパク質鸰料を選択させた場合には，選択開始 後 2 3 日間の攝取量, とくに亜鉛条件を前飼料と変えた 群で高タンパク質飼料の摂取量に大きな変化を認めた (実験 I-2)。そこで, 初めの 3 日間およびその後の 8 日間 の摄取量に分けて分散分析を行った。その結果を Table 2 に示す。 $20 \%$ DP 飼料を前飼料としたラットで は選択開始の 3 日間の低タンパク質飼料捸取量と高タン パク質飼料摂取量のいずれにも前飼料中の亜鉛量の影骇 を認めた。4 日目以降の高タンパク質飼料の摄取量につ

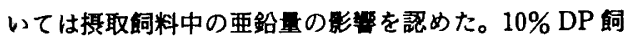
料を前飼料としたラットでは高タンパク貿飼料の選択摄 取量は捸取飼料中の覀鉛量の影響が大きかった。前飼料 中のタンパク質レペルにかかわらず，選択期間中の低夕

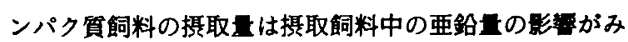
られなかったが, 選択 4 日目以後の高タンパク質飼料と 総摄取量については摄取飼料中の亜鉛量の影粱がみられ た。亜鉛欠乏ラットは低タンパク質飼料を多く選択する とした Reeves and O'Dell ${ }^{2)}$ の結果とは異なり，20\% DP 亜鉛欠乏飼料を前飼料として摄取させた後に選択させた ラットは低タンパク質飼料を多く選択しなかった。亜鉛 欠乏条件で高タンパク質飼料の捸取量が減少したことに

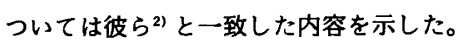

要鉛欠乏飼料を摄取したラットの飼料摄取量の低下お よび成長の抑制はその後の亜鉛含有飼料投与で回復し, 逆に，垔鉛含有飼料摂取ラットの飼料摂取量と体重の増 加量はその後の要鉛欠乏飼料投与により抑制された。こ の傾向は低タンパク貿飼料と高タンパク質飼料のいずれ の飼料を前飼料とした条件でも同様に認められた (Table 2)。Table 3 に血清アルカリフォスファターゼ 活性，血清および大腿骨の亜鉛の港度変化を示す。亜鉛 欠乏ラットにおいて血清アルカリフォスファターゼ活 性，血清および大駺骨の亜鉛算度が速やかに減少した ラットほど生存期間も短縮されたことから，これらの測 定值はラット体内亜鉛状態の指標となりうることを明ら かにしている ${ }^{113)}$ 。Table 3 の結果も体重の変化と同じ傾 向を示し,飼料の亜鉛条件をよく反映した変動を認めた。 このことは, ラットの体内亜鉛状態が高タンパク質飼料 摄取量および総摄取量と密接な関係にあることを示して いる。

$20 \%$ DP 垔鉛適量飼料を前飼料としたラットは低タン パク質飼料に比へて高タンパク質飼料を選択したが, $10 \%$ DP 飼料を前飼料としたラットではそうではなかっ た (Fig. 2)。ラットの飼料タンパク質レベルの選択性は 飼料中の亜鉛量 ${ }^{2)}$ のみでなく，前飼料で用いた飼料中の 


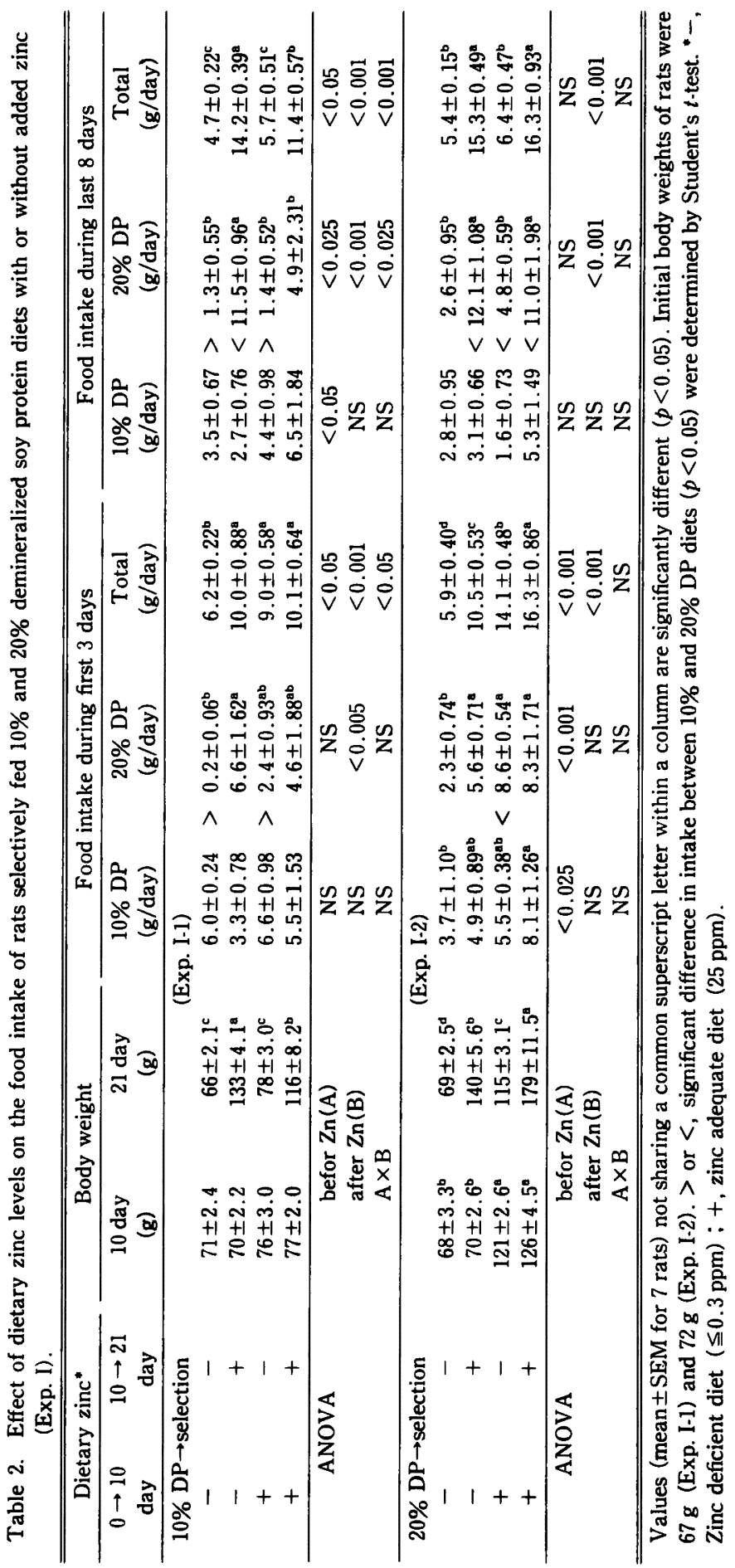


Table 3. Effects of dietary zinc levels on serum alkaline phosphatase activity and zinc concentration in serum and femur of rats (Exp. I-1, I-2).

\begin{tabular}{|c|c|c|c|c|c|c|}
\hline & $\begin{array}{c}\text { Day of } \\
\text { sacrifice }\end{array}$ & Dietary & inc & $\begin{array}{c}\text { Serum APase } \\
\text { activity } \\
\text { (K-A unit) }\end{array}$ & $\begin{array}{c}\text { Serum zinc } \\
(\mu \mathrm{g} / \mathrm{ml})\end{array}$ & $\begin{array}{c}\text { Femur zinc } \\
\text { ( } \mu \mathrm{g} / \mathrm{g} \text { dry wt.) }\end{array}$ \\
\hline \multirow[t]{3}{*}{ Exp. I-1 } & 0 day & & & $59.8 \pm 2.77^{a}$ & $1.71 \pm 0.048^{\mathrm{a}}$ & $186 \pm 6.0^{a}$ \\
\hline & 10 day & & $\begin{array}{l}\% \mathrm{D} \\
- \\
+\end{array}$ & $\begin{array}{l}34.1 \pm 2.28^{\mathrm{b}} \\
52.1 \pm 4.11^{\mathrm{a}}\end{array}$ & $\begin{array}{l}0.50 \pm 0.031^{\mathrm{d}} \\
1.08 \pm 0.054^{\mathrm{b}}\end{array}$ & $\begin{array}{l}100 \pm 2.6^{d} \\
176 \pm 3.1^{b}\end{array}$ \\
\hline & 21 day & $\begin{array}{ll} & \text { se } \\
(- & \rightarrow) \\
(- & \rightarrow) \\
(+ & \rightarrow) \\
(+ & \rightarrow)\end{array}$ & $\begin{array}{l}\text { lectic } \\
- \\
+ \\
- \\
+\end{array}$ & $\begin{array}{l}18.4 \pm 2.57^{\mathrm{c}} \\
56.9 \pm 3.01^{\mathrm{a}} \\
20.0 \pm 2.71^{\mathrm{c}} \\
52.7 \pm 2.21^{\mathrm{a}}\end{array}$ & $\begin{array}{l}0.44 \pm 0.082^{\mathrm{d}} \\
1.27 \pm 0.041^{\mathrm{b}} \\
0.72 \pm 0.107^{\mathrm{c}} \\
1.15 \pm 0.052^{\mathrm{b}}\end{array}$ & $\begin{array}{r}67 \pm 0.9^{\mathrm{e}} \\
134 \pm 2.8^{\mathrm{c}} \\
105 \pm 3.9^{\mathrm{d}} \\
174 \pm 2.8^{\mathrm{b}}\end{array}$ \\
\hline \multirow[t]{3}{*}{ Exp. I-2 } & 0 day & & & $71.0 \pm 3.65^{\mathrm{ab}}$ & $1.60 \pm 0.049^{a}$ & $174 \pm 5.1^{\circ}$ \\
\hline & 10 day & & $\begin{array}{l}\% \mathrm{D} \\
- \\
+\end{array}$ & $\begin{array}{l}26.8 \pm 2.78^{\mathrm{d}} \\
75.0 \pm 4.46^{\mathrm{a}}\end{array}$ & $\begin{array}{l}0.61 \pm 0.074^{\mathrm{d}} \\
1.07 \pm 0.029^{\mathrm{bc}}\end{array}$ & $\begin{array}{r}81 \pm 3.2^{e} \\
150 \pm 1.9^{b}\end{array}$ \\
\hline & 21 day & $\begin{array}{ll} & \\
(- & \rightarrow) \\
(- & \rightarrow) \\
(+ & \rightarrow) \\
(+ & \rightarrow)\end{array}$ & $\begin{array}{l}\text { lectic } \\
- \\
+ \\
- \\
+\end{array}$ & $\begin{array}{l}23.2 \pm 1.98^{\mathrm{d}} \\
63.2 \pm 2.59^{\mathrm{bc}} \\
24.7 \pm 2.15^{\mathrm{d}} \\
57.1 \pm 2.14^{\mathrm{c}}\end{array}$ & $\begin{array}{l}0.35 \pm 0.043^{\mathrm{e}} \\
0.95 \pm 0.045^{\mathrm{c}} \\
0.66 \pm 0.091^{\mathrm{d}} \\
1.17 \pm 0.057^{\mathrm{b}}\end{array}$ & $\begin{array}{r}60 \pm 1.7^{\mathrm{r}} \\
114 \pm 2.9^{\mathrm{c}} \\
97 \pm 5.2^{\mathrm{d}} \\
158 \pm 4.8^{\mathrm{b}}\end{array}$ \\
\hline
\end{tabular}

Values (mean \pm SEM for 7 rats) not sharing a common superscript letter within a column and each of the previous dietary protein levels (Exp. I-1 and I-2) are significantly different $(p<0.05)$.

垔鉛量およびタンパク買量の影䉕をも受けることを示し ている。

2. 前蚼料として高，低タンパク面铜料を選択捸取さ せた後の垔鉿欠乏ラットの飼料選択性（実験 II）

前飼料タンパク貿レベルの影要をなくした場合の亜鉛 欠乏ラットの咱料選択性を調へたた。毎日の攝取量の変化 を Fig. 3 に示す。要鉛欠乏条件で選択させるとラットは 低タンパク質飼料を多く選択した。要鉛適量条件下で選 択させたラットは高タンパク質䣳料の摄取量がしだいに 増加した。10日目以後要鉛条件を変更したラットでは高 タンパク質眗料の捸取量は大きく変化したが, 低タンパ ク質咱料摂取量には変化を訊めなかった。Table 4 に垔 鉛条件を変更した後の, 3 日間とその後の 8 日間の秱料 摂取量および分散分析の結果を示す。初期の 3 日間には 高タンパク質飼料摂取量に前飼料中亜鉛量の影䈏を認め たが，4 日目以降の高タンパク質飼料の摂取量および総 摂取量は摄取飼料中の要鉛量の影策を受け, 垔鉛欠乏条 件で減少し, 垔鉛適量条件で著しく增加した。本実験で の 10 日目以後亜鉛条件を変更したラットの飼料選択性 は, 実験 Iの $20 \%$ DP 飼料を前飼料としたラットの結果 とほほ同様となった。

亜鉛条件を継続したラットの 10 日目以降の飼料の攝
取量および選択傾向がほほ維持された（Fig. 3）ことは ラットが高タンパク質飼料への順応に 10 日間程度を要 することを示し, 飼料中の亜鉿量への順応に2 3 日を 要したのと比べる䐅かった。これらの事実が, 実験 Iに おいて $10 \%$ DP 飼料を前秱料としたラットが高タンパ ク質飼料摄取への応答が少なかったことにも反映したも のと思われる。

亜鉛欠乏ラットは高タンパク筫飼料の攝取量を娍少さ せ, 亜鉛の補給は高タンパク頜飼料の選択性を增大させ た。一方, 垔鉛欠乏ラットの絰椇取量の減少は, 高タン パク質眗料の選択性の低下を低タンパク䨘餇料の增加で 補うことができないことを示し，高タンパク䨘飼料の選 択性の低下がラットのタンパク質摄取量の抑制にあるな らば $10 \%$ DP 飼料もすてにタンパク質過剩飼料である ことを示している。

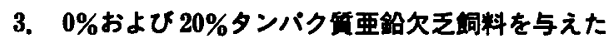
ラットの詞料㩧択性およひ生存期间（实硂 III）

垔鉛欠乏ラットが自由にタンパク筫摄取量を調節でき る条件を用いた。 5 日間ごとの飼料摄取量の変化を Fig. 4 に示す。実験開始 8 日間は $20 \%$ DP 飼料のほうを無夕 ンパク質飼料よりも多く選択したがその後はほとんど選 択しなくなった。体重は $20 \% \mathrm{DP}$ 飼料群，選択群,0\% DP 


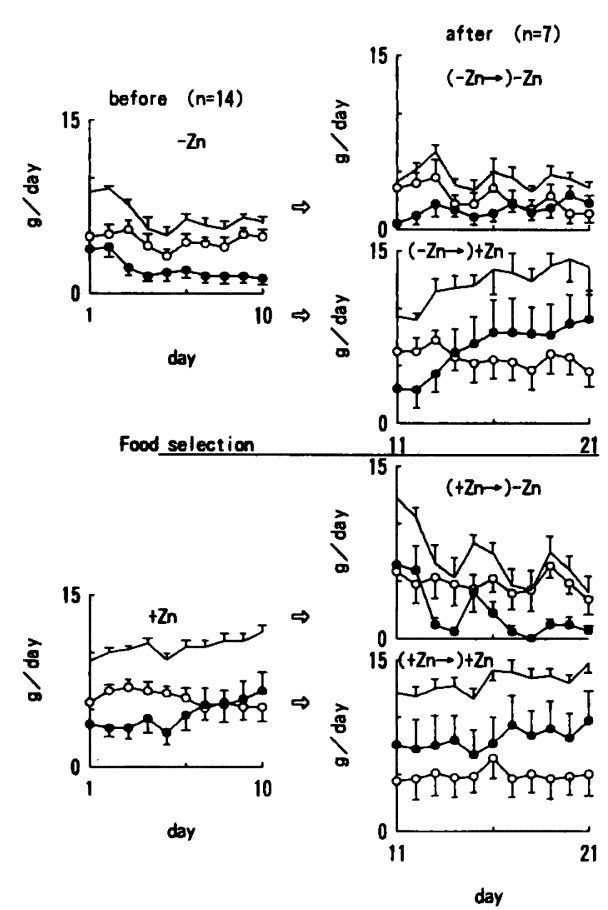

Fig. 3. Changes in food intake of rats selectively fed $10 \%$ and $20 \%$ demineralized soy protein diets with or without added zinc (Exp. II).

Q, $10 \%$ DP diet : $\bullet, 20 \%$ DP diet :- total amount of food intake. Values are means \pm SEM for 7 rats.

飼料群の順に大きかった。選択群のラットは $20 \% \mathrm{DP}$ 飼 料単独群および $0 \%$ DP 飼料単独群と比へて緩やかに体 重が減少した。ラットの生存期間を Fig. 5 に示す。 $20 \%$ DP 飼料群に対して 0\% DP 飼料群の生存期間は有意に 長く, 選択群では $0 \% \mathrm{DP}$ 飼料群よりさらに延長する傾 向を認めた。無タンパク質飼料を摄取したラットの亜鉛 要求性は $20 \%$ タンパク質飼料を摂取したラットに比へ て低いことを示唆している。こうした傾向は Table 5 に 示す血清アルカリフォスファターゼ活性および大駺骨要 鉛濃度の変化にも認められ, $20 \%$ タンパク質飼料群より 選択摂取群，さらに無タンパク質咱料群で緩やかに減少 した。Chesters and Quarterman" は無タンパク質飼料 の条件で垔鉛欠乏飼料および吿鉛含有飼料を同時にラッ トに与えるとそれぞれ同じ量を選択するが，選択させる 飼料にタンパク質が含まれると要鉛含有姛料を選択する ことを報告しており，飼料選択性に対するタンパク質と 亜鉛の関係は本実験結果と類似した関係を示したものと

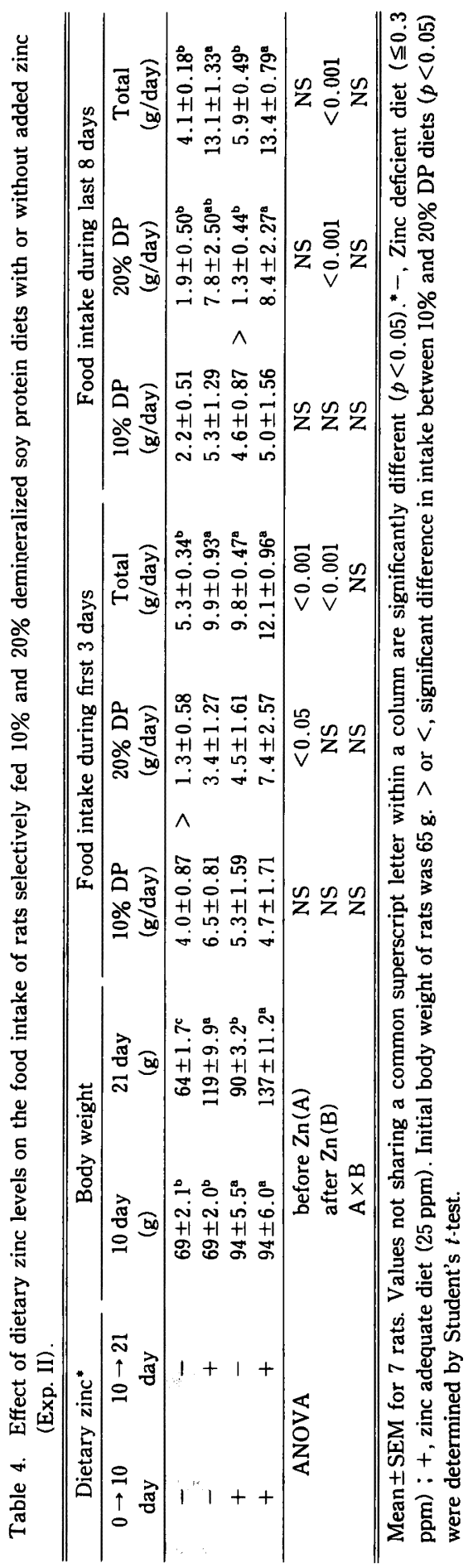


いえる。しかし，亜鉛欠乏条件においてタンパク買の摄 取を積極的に避けるという内容まては含んでいない。 亜鉛欠乏飼料を摂取させたラットへ亜鉛を投与すると 骨の垔鉛量の回復よりもタンパク貿合成醭素系の回復の 程度が大きく ${ }^{15)}$, 骨よりもタンパク質合成系への亜鉛の 優先的利用が示唆され ${ }^{16)}$ ，すてに報告したように体内亜 鉛の不足状㮩は骨などの優先されない組織において亜鉛 量の変化が大きい方。摄取タンパク質量の増加は体内夕 ンパク質合成を元進させ, その際に要求される亜鉛量の

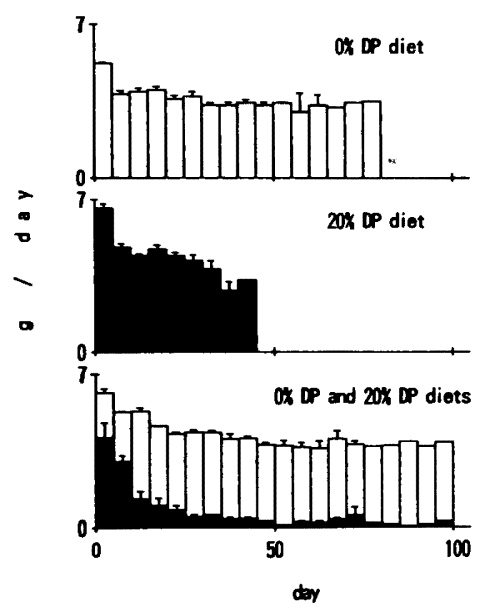

Fig. 4. Changes in food intake of rats selectively fed non protein diet and $20 \%$ demineralized soy protein diet without added zinc (Exp. III).

$\square, 0 \%$ DP diet : $\square, 20 \%$ DP diet. Values are means (for $1 \sim 8$ rats) $\pm S E M$ (for $3 \sim 8$ rats) of each diet. Food intakes were shown every 5 days.
増加により体内亜鉛が不足することが考えられる。実際 タンパク質合成が穴進される条件で大腿骨重鉛湌度の変 動は著し(い17)。

Fig. 4, 5 および Table 5 に示す結果は, 亜鉛欠乏ラッ トがタンパク質摂取量をごくわずかに抑制することに よって自己の生存をより良い方向へ焉く樌極的な行動て あることを示している。タンパク質摂取量の減少により 体内垔鉛要求量を低下させ，西鉛欠乏下における生存を より有利にさせることも亜鉛欠乏飼料を攝取したラット の飼料摄取吾が数日のうちに減少する ${ }^{8)-10)}$ 原因の一つ であると思われる。

要

約

1）垔鉛欠乏または亜鉛適量の飼料を前飼料として 10 日間与えたラットに $10 \%$ と $20 \%$ タンパク賢䣳料の 2 種類の飼料を同時に与え，その選択性を調へた。亜鉛遧 量条件で選択したラットては $20 \%$ タンパク質飼料の撖

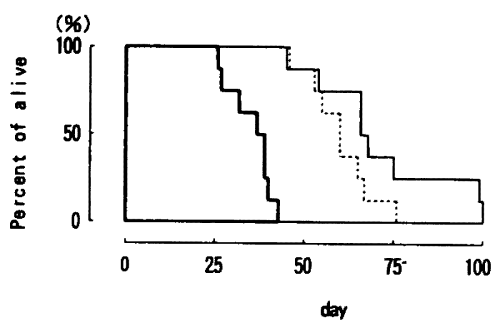

Fig. 5. Survival rate of zinc deficient rats selectively fed non protein diet and 20\% demineralized soy protein diet without added zinc (Exp. III).

$\cdots, 0 \%$ DP diet : $\longrightarrow, 20 \%$ DP diet. : - , $0 \%$ DP diet and 20\% DP diet.

Table 5. Changes in alkaline phosphatase activity in serum and zinc concentration in serum and femur of rats selectively fed $0 \%$ and $20 \%$ demineralized soy protein diets without zinc (Exp. III).

\begin{tabular}{|c|c|c|c|c|}
\hline $\begin{array}{l}\text { Day of } \\
\text { sacrifice }\end{array}$ & $\begin{array}{c}\text { Dietary protein } \\
\text { level }\end{array}$ & $\begin{array}{c}\text { Serum APase activity } \\
\text { (K-A unit) }\end{array}$ & $\begin{array}{l}\text { Serum zinc } \\
(\mu \mathrm{g} / \mathrm{ml})\end{array}$ & $\begin{array}{c}\text { Femur zinc } \\
\text { ( } \mu \mathrm{g} / \mathrm{g} \text { dry wt.) }\end{array}$ \\
\hline \multirow{3}{*}{2 day } & $0 \%$ & $72.3 \pm 3.3^{\mathrm{ab}}$ & $1.15 \pm 0.055^{\mathrm{s}}$ & $155 \pm 5.1^{\mathrm{s}}$ \\
\hline & $20 \%$ & $92.3 \pm 5.5^{\mathrm{a}}$ & $0.27 \pm 0.024^{\mathrm{d}}$ & $125 \pm 5.2^{b c}$ \\
\hline & $0 \%$ and $20 \%$ & $76.5 \pm 4.2^{\mathrm{ab}}$ & $0.31 \pm 0.039^{d}$ & $130 \pm 4.5^{\mathrm{bc}}$ \\
\hline \multirow{3}{*}{6 day } & $0 \%$ & $66.3 \pm 6.9^{b}$ & $0.74 \pm 0.051^{b}$ & $138 \pm 2.4^{b}$ \\
\hline & $20 \%$ & $38.7 \pm 3.1^{c}$ & $0.45 \pm 0.061^{\mathrm{cd}}$ & $82 \pm 4.1^{\mathrm{d}}$ \\
\hline & $0 \%$ and $20 \%$ & $63.6 \pm 6.6^{\mathrm{b}}$ & $0.53 \pm 0.073^{c}$ & $89 \pm 7.1^{\mathrm{d}}$ \\
\hline \multirow{3}{*}{21 day } & $0 \%$ & $66.3 \pm 7.7^{\circ}$ & $0.47 \pm 0.028^{\mathrm{cd}}$ & $119 \pm 4.2^{\mathrm{c}}$ \\
\hline & $20 \%$ & $42.0 \pm 4.8^{c}$ & $0.28 \pm 0.027^{\mathrm{d}}$ & $46 \pm 0.9^{1}$ \\
\hline & $0 \%$ and $20 \%$ & $56.5 \pm 9.3^{\text {bc }}$ & $0.42 \pm 0.067^{\mathrm{cd}}$ & $66 \pm 6.3^{e}$ \\
\hline
\end{tabular}

Mean \pm SEM for 5 rats. Values not sharing a common superscript letter within a column are significantly different $(p<0.05)$. Each diet contained $\leqq 0.2 \mathrm{ppm}$ zinc. 
取量が増加し，要鉛欠乏条件で選択したラットでは $20 \%$ タンパク質飼料の摂取量が減少した。10\%タンパク筫飼

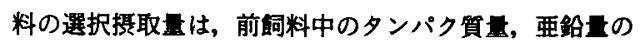
影零を受けず, また摄取している飼料中の亜鉛量の影要 を受けなかった。

2）前飼料中の亜鉿量の影要は，その後の選択摄取開 始 3 日間の飼料の掫取贯についてみられたが, それ以降 の摄取田は摄取している眗料中の亜鉊量の影需を受け た。

3） $0 \%$ よひ $20 \%$ タンパク貫垔鉛欠乏飼料の 2 類 の飼料を選択させたラットは 9 日目以降 20\%タンパク 質飼料を選択せず,無タンパク質咱料をおもに選択した。 その結果, それぞれの同料を単独て掜取したラットに比 べて生存期間は延艮した。

4）ラットは体内悪鉛状慜を維持するためにタンパク 嘪の摄取早を調節でることが示唆された。

\section{文献}

1）則井孝文，鈴榑雄：栄食誌，43，247（1990）

2) Reeves, P.G. and O'Dell, B.L.: J. Nutr., 111, 375 (1981)
3) Chesters, J.K. and Will, M. : Br. J. Nutr., 30, 555 (1973)

4) Griffith, P.R. and Alexander, J.C. : Nutr. Rep. Int., 6. 9 (1972)

5) Faraji, B. and Swendseid, M.E. : J. Nutr., 113, 447 (1983)

6) Flanagan, P.R. : J. Nutr., 114, 493 (1984)

7) Park, J.H.Y., Grandjean, C.J., Antonson, D.L. and Vanderhoof, J.A. : J. Nutr., 116, 610 (1986)

8) Williams, R.B. and Mills, C.F.: Br. J. Nutr., 24, 989 (1970)

9) Chesters, J.K. and Quarterman, J. : Br. J. Nutr., 24, 1061 (1970)

10) Swenerton, H. and Hurley, L.S. : J. Nutr., 95, 8 (1968)

11) McConnell, S.D. and Henkin, R.I. : J. Nutr., 104, 1108 (1974)

12) Harper, A.E. : J. Nutr., 68, 405 (1959)

13）則井事文, 鈴木博雄：栄食誌，43，255（1990）

14) Snedecor, G.W. and Cochran, W.G. : 統計的方法（㚼 村又良, 奥野忠一, 津村善郎共訳), 246 (1972), 岩 波㶳店（果京）

15) Hicks, S.E. and Wallwork, J.C. : J. Nutr., 117, 1234 (1987)

16) Stuart, S.M., Ketelsen, S.M., Weaver, C.M. and Erdman, J.W., Jr. : J. Nutr., 116, 1423 (1986)

17）則井孝文, 鈴木博雄：栄食誌，44，113（1991）

(1993 年 10 月 28 日受理) 